\title{
Composting of Food Waste and Mixed Poultry Manure Inoculated with Effective Microorganisms *
}

\author{
Keumjoo PARK ${ }^{* 1}$
}

\begin{abstract}
Food waste and poultry manure mixes inoculated with effective microorganisms (EM) were composted by a rotating drum composter under initial moisture conditions of $63-74 \%$ (w.b). Composting was performed for 24 hrs using steam from a firewood boiler $(450 \mathrm{MJ} / \mathrm{hr})$ which heated the composting mass in order to maintain the temperature of the compost between 60 and $80^{\circ} \mathrm{C}$. Parameters monitored over this period included the nutrient content, heavy metal content, maturity and stability indices etc. Changes in $\mathrm{pH}$, moisture content, $\mathrm{EC}$ (electrical conductivity), $\mathrm{NaCl}$ and $\mathrm{C} / \mathrm{N}$ during composting were consistent with those generally observed in ordinary composting systems. The parameters were influenced by the feedstock materials but not affected by inoculation with EM. The C/N ratios and moisture content of the composts decreased with the composting time. The $\mathrm{NaCl}$ content of the food waste compost increased with composting time but was less than $1.0 \%$ (d.b). For the finished food waste compost, the compost stability index, based on oxygen uptakes, was less than $0.3 \mathrm{mg} / \mathrm{g}$ VS $\mathrm{hr}$ and the compost maturity index, based on seed germination rates, was greater than $80 \%$. The finished food waste compost could be utilized for land improvement whereas that using food waste amended with poultry manure could not be utilized.
\end{abstract}

[Keywords] food waste, poultry manure, effective microorganism, composting, germination rate.

\section{Introduction}

Composting is a process which deals with the biological decomposition and stabilization of organic substrates. Composting systems utilize degradable constituents to produce $\mathrm{CO}_{2}, \mathrm{H}_{2} \mathrm{O}, \mathrm{NH}_{3}$ and biological heat as the major products. The final product at the end of the maturation process should be stable and can be applied to soil to improve its physical, chemical and biological properties. Nutrients, heavy metals, temperature, aeration rates, effective microorganisms (EM), odor generation and the cost of composting should be considered for the effective composting of biological wastes. A major problem in aerobic composting of biological wastes is the odor caused by the release of ammonia, which is a byproduct from the composting of low $\mathrm{C} / \mathrm{N}$ material (Hong et al., 1999).

The use of EM to initiate the composting process could reduce composting time (Misra et al., 2003), heavy metals in compost, odor production and ammonia volatilization (Lee \& Cho, 2010). Work done elsewhere was inconclusive with regard to the effectiveness of EM in speeding up composting (Faure and Deschamps 1991). Co-composting of food waste and animal manure with inoculated EM provides a good solution to the problems associated with food wastes and animal manure management. On the other hand, composting of organic wastes with EM did not positively influence the composting process. The parameters such as $\mathrm{pH}$, electrical conductivity (EC) and the $\mathrm{C} / \mathrm{N}$ ratio were influenced by the feedstock materials used but were not affected by inoculation with EM (Mupondi, et al., 2006).

Compost stability and maturity are important factors affecting the successful use of composts in agriculture (Mathur et al. 1993). This is because the application of unstable composts can cause low plant growth rates and damage crops by competing for oxygen or causing phyto-toxicity in plants due to insufficient biodegradation of organic matter (Keeling et al.1994).

Although there is no one single method to evaluate maturity (Inbar et al.,1990), the producers and users of compost accept several methods to assess the stability and maturity. For stability, it is recommended that that respiration as measured by oxygen uptake is used. A seed germination test can be used for maturity (Epstein, 1997).

The objective of this research was to evaluate the stabilization capabilities of food waste composting and food

* This paper was supported by research fund of Cheonnam Province and Youngam County in 2009.

*1 KSAM Member, Dept. of Industrial Machinery Engineering, Sunchon National University, 315 Maekok-dong, Sunchon-si, Republic of Korea ; pkj@sunchon.ac,kr 
waste amended with poultry manure through co-composting when inoculated with the EM system.

\section{Materials and Methods}

The composting process is composed of preliminary operations, pretreatment, biological reaction and refinement as shown in Fig. 1.

\section{Preliminary operations}

The food waste sludge ( $\mathrm{Fw}$ ) was dewatered and screened to control the moisture content and eliminate impurities such as vinyl, plastics etc., and mixed with poultry manure if necessary to make the initial feedstock (IF).

\section{Pretreatment}

The $1^{\text {st }}$ drying reactor inoculated with the additive EM reduced the moisture content (MC) of the IF using steam heated by firewood boiler $(450 \mathrm{MJ} / \mathrm{hr})$. The first $15 \mathrm{~m}^{3}$ (drying reactor) and the second $30 \mathrm{~m}^{3}$ (composter) working-volume reactors as shown in Figure 2 were controlled for composting mass in the range $60-80^{\circ} \mathrm{C}$, with a detention time of $3 \mathrm{hrs}$ and $24 \mathrm{hrs}$, respectively, using steam from the firewood boiler.

\section{Composting}

Inoculation with $1 \mathrm{~kg} \mathrm{EM} / \mathrm{ton}$ of the IF followed by deactivation of weed seeds and plant parasites. Optimum decomposition occurred at a temperature within in the range of 60 to $70^{\circ} \mathrm{C}$ in the $2^{\text {nd }}$ reactor $\left(30 \mathrm{~m}^{3}\right)$ with the optimal moisture content of the mature compost of less than $30 \%$ (w.b) being obtained using the same firewood boiler $(450 \mathrm{MJ} / \mathrm{h})$ and aerator $\left(25 \mathrm{~m}^{3} / \mathrm{h}\right)$.

\section{Refinement of the mature compost}

Samples were obtained by Boorim Tec. Co., Ltd. which owned the composting facilities. Samples of the raw material (food waste: Fw, poultry manure: Pm), initial feedstock (IF), intermediate compost (IC) and finished compost (FC) were collected according to the composting stage and were stored at $4{ }^{\circ} \mathrm{C}$ if they were not analyzed immediately. The Boorim Tec. Co., Ltd. also provided some information on the compost management system. Food waste (Fw) was mainly composed of cooked fruit, vegetable, cereal, fish and meat scraps $(<$ $1 \mathrm{~cm})$. Raw poultry manure $(\mathrm{Pm})$ came from the Nara chicken farm (Pocheon, Gyunggi, South Korea). Samples were collected three times, before, during and after composting of the IF, IC and FC, respectively.

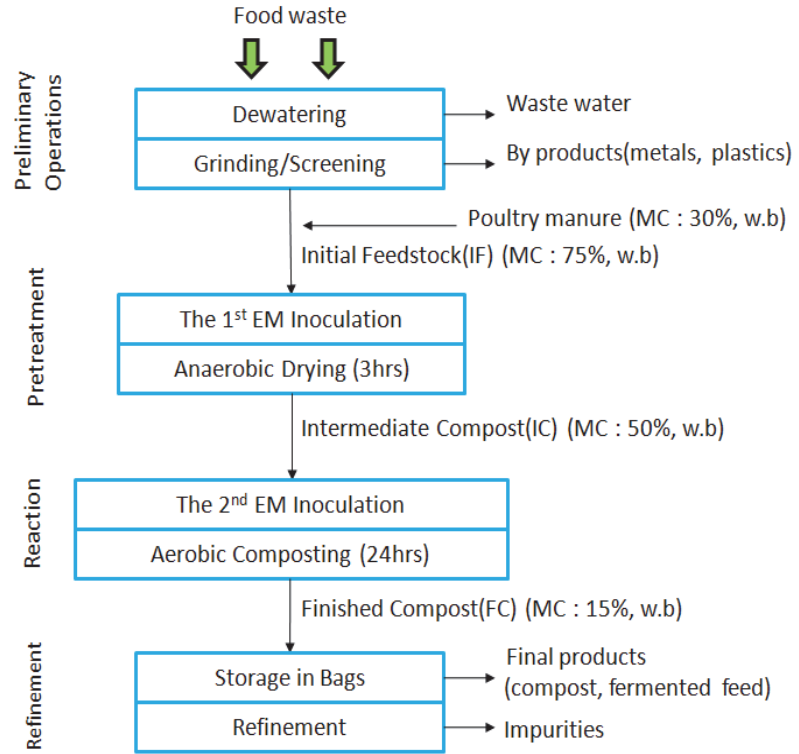

Fig. 1 Composting process of food waste and poultry manure.
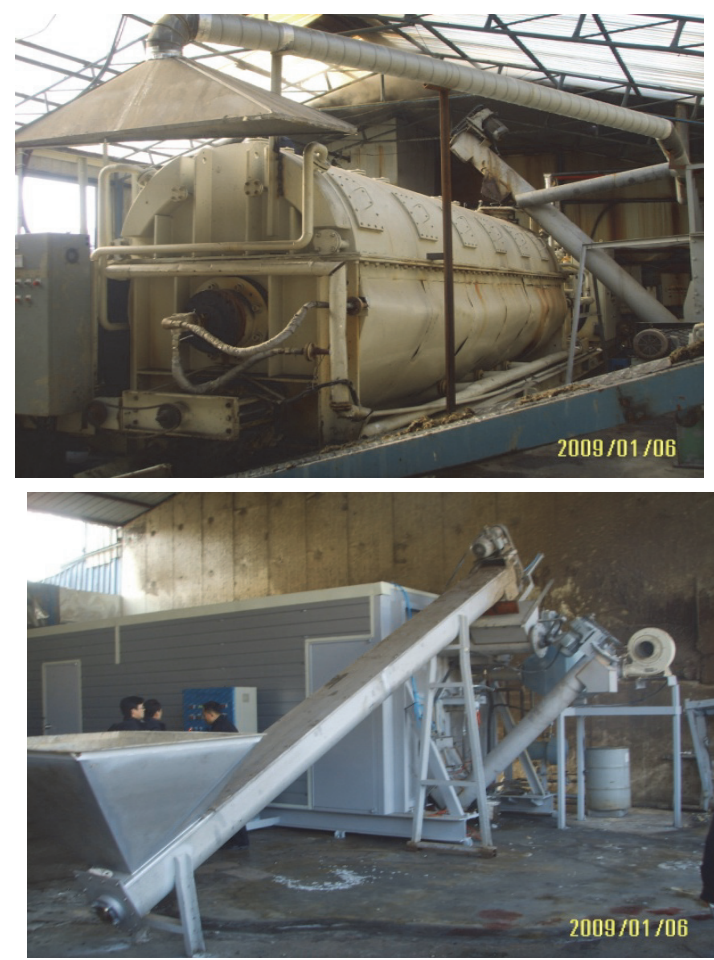

Fig. 2 Anaerobic drying reactor (upper) and rotating drum type aerobic composting reactor (lower).

The two treatments evaluated in this experiment were: (a) food wastes only and (b) food wastes $(50 \%)+$ raw poultry manure $(50 \%)$. Analysis was undertaken for the samples of IF, IC and FC with three replications, representing replication signals as f1, f2, f3 (food waste alone) and m1, m2, m3 (mixed feedstock of food waste and poultry manure). The 
items analyzed were the physicochemical properties, nutrient content, heavy metal content and stability index etc. At each sampling one composite sample was obtained for every compost sample collected at random positions in the composting mixtures. The physicochemical properties, nutrient and heavy metal content were determined as described by the RDA (1989). Seed germination rate and oxygen respiration rate were measured as noted by Zucconi et al. (1981) using a respirometer (AER-208).

\section{Results and Discussion}

\section{Changes in physicochemical parameters}

The physicochemical characteristics of the IFf, ICf, FCf, $\mathrm{Pm}, \mathrm{Fw}, \mathrm{IFm}$ and $\mathrm{FCm}$ during the composting process are presented in Tables 1 and 2. The $\mathrm{pH}$ value of the initial and final compost was found to be in an acid condition. The moisture content reduction from $63-74 \%$ (w.b) of the IF to 6 - $31 \%$ (w.b) of the MC at the end of the process occurred gradually throughout the composting period. The $\mathrm{NaCl}$ content of $0.4-0.5 \%$ (d.b) of the IFf rose to $0.7-1.0 \%$ (d.b) of the FCf. This value was near to the maximum level of $1.0 \%$ (d.b) required for the matured compost (RDA, 2009). On the other hand, the $\mathrm{NaCl}$ content of the food waste amended with poultry manure compost $(\mathrm{FCm})$ was greater than $1.6 \%$ (d.b) showing a harmful indicator.

The increase in the total carbon $(\mathrm{C})$ and nitrogen $(\mathrm{N})$ content with time, was the result of the reduction in organic matter. The $\mathrm{C} / \mathrm{N}$ ratio of the final compost was in the range 6 -
13 and consequently satisfactory to prevent plant roots and soil microorganisms competing for nitrogen (Vogtmann and Fricke 1989). The $\mathrm{C} / \mathrm{N}$ ratios of the FCf and $\mathrm{FCm}$ ranged from 6 to 13 as shown in Table 1. The finished compost had an average $\mathrm{C} / \mathrm{N}$ ratio of 10 . This value shows $\mathrm{C} / \mathrm{N}$ ratios lower than the threshold $\mathrm{C} / \mathrm{N}$ ratio of 20 (Hong et al., 1999).

The EC of the initial feedstock ranging from 24 to $33 \mathrm{dS} / \mathrm{m}$ increased to values from 33 to $58 \mathrm{dS} / \mathrm{m}$ at the end of the composting process as shown in Tables 1 and 2. These high EC values probably resulted from the high degree of decomposition of the organic materials and the release of their nutrient content.

Data obtained by Raviv et al. (1987) and Inbar et al. (1993) indicated a drop in conductivity early in the composting process followed by a steady increase as the process proceeds. The initial drop is attributed to the fixing of ammonia and other nutrients ions during the rapid increase in the aerobic microbial population, while the subsequent increase is due to the concentration of minerals in the final stages of active composting. Epstein (1997) suggests that EC levels in excess of $5 \mathrm{ds} / \mathrm{m}$ may lead to phytotoxicity.

The only unexpected result was the higher than normal EC of the finished compost which correlated with the increased concentration of salts in the food wastes, however the quality of the food waste compost was suitable for use in agricultural applications according to current practices.

Table 1 Physicochemical properties of the IF, IC and FC during the composting process.

\begin{tabular}{l|ccccccc}
\hline & $\begin{array}{c}\mathrm{pH} \\
(-)\end{array}$ & $\begin{array}{c}\mathrm{MC} \\
(\%, \mathrm{wb})\end{array}$ & $\begin{array}{c}\mathrm{NaCl} \\
(\%, \mathrm{db})\end{array}$ & $\begin{array}{c}\text { Total-C } \\
(\%, \mathrm{db})\end{array}$ & $\begin{array}{c}\text { Total-N } \\
(\%, \mathrm{db})\end{array}$ & $\begin{array}{c}\mathrm{C} / \mathrm{N} \\
(-)\end{array}$ & $\begin{array}{c}\text { EC } \\
(\mathrm{dS} / \mathrm{m})\end{array}$ \\
\hline IFf1 & 5.1 & 70 & 0.38 & 14.76 & 1.12 & 13 & 28.5 \\
IFf2 & 5.1 & 66 & 0.41 & 15.14 & 1.13 & 13 & 29.4 \\
IFf3 & 5.1 & 67 & 0.46 & 16.01 & 1.26 & 13 & 25.7 \\
ICf1 & 5.1 & 62 & 0.48 & 17.20 & 1.42 & 12 & 28.6 \\
ICf2 & 5.7 & 50 & 0.56 & 23.32 & 1.31 & 18 & 30.7 \\
ICf3 & 5.8 & 59 & 0.56 & 18.16 & 1.57 & 12 & 25.2 \\
ECf1 & 4.8 & 11 & 0.65 & 39.70 & 3.40 & 12 & 32.7 \\
ECf2 & 5.3 & 31 & 1.00 & 32.30 & 2.70 & 12 & 45.9 \\
ECf3 & 5.4 & 11 & 0.99 & 40.78 & 3.12 & 13 & 50.2 \\
\hline
\end{tabular}


PARK:

Table 2 Physicochemical properties of Pm, Fw, IF and FC of food waste amended with poultry manure during EM composting.

\begin{tabular}{lccccccc}
\hline & $\begin{array}{l}\mathrm{Ph} \\
(-)\end{array}$ & $\begin{array}{c}\mathrm{MC} \\
(\%, \mathrm{wb})\end{array}$ & $\begin{array}{c}\mathrm{NaCl} \\
(\%, \mathrm{db})\end{array}$ & $\begin{array}{c}\text { Total-C } \\
(\%, \mathrm{db})\end{array}$ & $\begin{array}{c}\text { Total-N } \\
(\%, \mathrm{db})\end{array}$ & $\begin{array}{c}\mathrm{C} / \mathrm{N} \\
(-)\end{array}$ & $\begin{array}{c}\mathrm{EC} \\
(\mathrm{dS} / \mathrm{m})\end{array}$ \\
\hline Pm1 & 7.9 & 72 & 0.56 & 9.80 & 1.8 & 5 & 33.8 \\
Pm2 & 7.5 & 75 & 0.50 & 10.40 & 1.6 & 7 & 29.0 \\
Pm3 & 7.5 & 75 & 0.44 & 10.10 & 1.6 & 6 & 30.6 \\
& & & & & & & \\
Fw1 & 5.3 & 71 & 0.46 & 12.80 & 1.2 & 11 & 23.8 \\
Fw2 & 5.4 & 72 & 0.48 & 12.90 & 1.3 & 10 & 28.5 \\
Fw3 & 5.7 & 60 & 0.70 & 17.30 & 1.7 & 10 & 29.8 \\
& & & & & & & \\
IFm1 & 6.1 & 63 & 0.99 & 15.80 & 1.3 & 12 & 24.3 \\
IFm2 & 6.2 & 73 & 0.44 & 12.80 & 1.6 & 8 & 32.4 \\
IFm3 & 6.7 & 74 & 0.56 & 11.10 & 1.6 & 7 & 32.9 \\
& & & & & & & \\
FCm1 & 5.6 & 6 & 1.60 & 37.20 & 4.3 & 9 & 40.1 \\
FCm2 & 5.5 & 6 & 1.50 & 40.10 & 6.4 & 6 & 49.2 \\
FCm3 & 5.5 & 7 & 1.40 & 39.80 & 4.3 & 9 & 57.9 \\
\hline
\end{tabular}

Table 3 Nutrient and heavy metal content of the FCf and FCm.

\begin{tabular}{lccccccc}
\hline Property (\% d. m.) & FCf1 & FCf2 & FCf3 & FCm1 & FCm2 & FCm3 & Standard ** \\
& & & & & & & \\
\hline $\mathrm{OM}(\%, \mathrm{dm})$ & 68.5 & 55.6 & 70.3 & 64.2 & 69.2 & 68.7 & 25 \\
$\mathrm{~N}(\%, \mathrm{dm})$ & 3.4 & 2.7 & 3.1 & 4.3 & 6.4 & 4.3 & \\
$\mathrm{P}_{2} \mathrm{O}_{5}(\%, \mathrm{dm})$ & 2.0 & 2.1 & 2.4 & 2.7 & 1.2 & 2.8 & \\
$\mathrm{~K}_{2} \mathrm{O}(\%, \mathrm{dm})$ & 1.0 & 0.78 & 0.77 & 1.2 & 1.5 & 1.5 & \\
$\mathrm{CaO}(\%, \mathrm{dm})$ & 4.8 & 6.73 & 6.85 & 11.1 & 14.5 & 11.4 & \\
$\mathrm{MgO}(\%, \mathrm{dm})$ & 0.47 & 0.38 & 0.39 & 0.4 & 0.8 & 0.7 & \\
$\mathrm{Cd}(\mathrm{mg} / \mathrm{kg})$ & $* \operatorname{tr}$ & $\operatorname{tr}$ & $\operatorname{tr}$ & $\operatorname{tr}$ & $\operatorname{tr}$ & $\operatorname{tr}$ & 5 \\
$\mathrm{Hg}(\mathrm{mg} / \mathrm{kg})$ & $\operatorname{tr}$ & $\operatorname{tr}$ & $\operatorname{tr}$ & $\operatorname{tr}$ & $\operatorname{tr}$ & $\operatorname{tr}$ & 2 \\
$\mathrm{As}(\mathrm{mg} / \mathrm{kg})$ & $\operatorname{tr}$ & $\operatorname{tr}$ & $\operatorname{tr}$ & $\operatorname{tr}$ & $\operatorname{tr}$ & $\operatorname{tr}$ & 45 \\
$\mathrm{Cu}(\mathrm{mg} / \mathrm{kg})$ & 6 & 8 & 6 & 17 & 25 & 28 & 400 \\
$\mathrm{Zn}(\mathrm{mg} / \mathrm{kg})$ & 30 & 55 & 48 & 69 & 105 & 106 & 1000 \\
$\mathrm{~Pb}(\mathrm{mg} / \mathrm{kg})$ & 1 & $\operatorname{tr}$ & 11 & 4 & 23 & 30 & 130 \\
& & & & & & & 5 \\
\hline
\end{tabular}

*tr: trace.

**: Compost standard (RDA, 2009)

\section{Quality of finished compost (FC)}

The nutrient and heavy metal contents of the FCf1, FCf2, FCf3 and FCm1, FCm2, FCm3 after the composting process are presented in Table 3. The organic matter content of the FC was in the range of 56-70\% d.b., showing a higher value than the Korean standard (RDA, 2009). Organic matter content is a important items related to the soil quality for plant growth (Fricke and Vogtmann 1994).

Most of the major nutrients were present in high concentrations which suggested that the finished compost (FCf and FCm) can support plant growth. The heavy metal concentrations and major nutrient contents in the finished 
compost were acceptable compared to the standard (RDA, 2009).

\section{Compost stability and maturity}

The seed germination rate (Zucconi et al.1981) and oxygen respiration rate (Iannotti et al.1994) have been used as the principal tests for determining the phytotoxicity and maturity of the composts.

The germination rate is used as an indirect measure of compost maturity and for evaluation of the phytotoxicity. Jodice (1989) reported that the increase in the germination rate which occurs during composting is a result of compost stabilization. A germination rate of 70 percent indicates a low level of phyto-toxic substances. A germination rate greater than $80 \%$ is required to prove the absence of phytotoxicity. The germination rates of the finished compost with foodwaste only (FCf) ranged from 83 to $97 \%$, showing good maturity, while those of $\mathrm{FCm}$ ranged from 40 to $77 \%$, possibly showing phytotoxic effects on the plants as shown in Table 4.

Another method for evaluating the maturity or stability is the determination of microbial activity in compost based on the $\mathrm{O}_{2}$ uptake or $\mathrm{CO}_{2}$ evolution. Iannotti et al. (1994) reported that an $\mathrm{O}_{2}$ respiration rate of $0-1.0 \mathrm{mg} / \mathrm{g} \mathrm{VS} \cdot \mathrm{hr}$ was stable. Oxygen respiration rates for the FCf and FCm varied from 0.03 to 0.44 showing they were in a stable condition as shown in Table 4.

Table 4 Stability and maturity indices of the FCf and FCm.

\begin{tabular}{lcccccc}
\hline & FCf1 & FCf2 & FCf3 & FCm1 & FCm2 & FCm3 \\
\hline $\begin{array}{l}\text { Germination } \\
\text { Rate (\%) }\end{array}$ & 97 & 83 & 90 & 40 & 53 & 77 \\
\hline $\begin{array}{l}\mathrm{O}_{2} \text { Respiration } \\
(\mathrm{mg} / \mathrm{g} \text { VS. } \mathrm{hr})\end{array}$ & $0.03-0.25$ & $0.08-0.32$ & $0.04-0.28$ & $0.14-0.40$ & $0.15-0.44$ & $0.18-0.42$ \\
\hline
\end{tabular}

\section{Summary and Conclusions}

The physicochemical analysis of samples, before and after composting of the food waste alone and food waste amended with poultry manure were generally in line with expectations from the literature. The only unexpected result was the higher EC of the effluent compost, which correlated with the increased concentration of salts in the food wastes. The quality of the food waste compost meant that it was suitable for use in agricultural applications according to current practices and standards.

Seed germination and oxygen respiration rates of the compost and maturity and stability parameters, respectively, were used for monitoring of the composting of biological wastes (food wastes only and food wastes mixed with poultry manure) inoculated with EM in this study.

The following conclusions can be drawn from this study.

Oxygen respiration index tests showed that the effluent compost of the food waste only and the mixture of food waste and poultry manure had no phytotoxic effects. However, the compost using a mixture of food waste and poultry manure showed a relatively lower germination rate, showing harmful effects to the plants occurred. The EC of the effluent compost should be adjusted to levels below $5 \mathrm{dS} / \mathrm{m}$ so that compost will not inhibit plant growth. The EC ranged from 32.7 to $57.9 \mathrm{dS} / \mathrm{m}$ representing much higher values than the optimum possibly due to the high EC of the initial feedstock and concentration during composting. The food waste amended with poultry manure compost could not be utilized for land improvement because of phytotoxicity from $\mathrm{NaCl}$ of $1.6 \%$ $(\mathrm{dm})$, and a low seed germination rate of less than $77 \%$.

\section{Acknowledgements}

Funding for this research was provided by the Field Technology Development Programs of Youngam County in Korea. We also thank Mr. Y. H. Kim from the Green Special Ind. Co., Ltd. for his cooperation during the project.

\section{References}

Becker,G. and A. Kotter.1995. Standard measurement of compost maturity. In: Proceedings of the First Intern. Symposium. University Essen and Hamburg, p.40.

Epstein, E. 1997. The Science of Composting. Technomic Publishing Co. Inc., Basel, Switzerland.

Faure, D. and A.M. Deschamps. 1991. The effect of bacterial inoculation on the initiation of composting of grape pulps. 
PARK:

Bioresource Technology, 37:235-238.

Fricke, K. and H. Vogtmann. 1994. Compost quality-physical characteristics, nutrient content, heavy metals and organic chemicals. Toxicol. Environ. Chem.,43:95-114.

Grebus, M. E., M.E. Watson and H.A.J. Hoitink.1994. Biological, chemical and physical properties of composted yard trimmings as indicators of maturity and plant disease suppression. Compost Science and Utilization, 2(1):57-71.

Hong, J.H., K.J. Park, B.T. Chun and S.C Hong 1999. Animal Waste Recycling.(In: Korean) The Dongwha Publishing Co. Inc., Seoul, Korea

Iannotti, D.A., M. E. Grebus, B.L. Toth, L. V. Madden and H.A. J. Hointink. 1994. Oxygen respirometry to asses stability and maturity of composted municipal solid waste. J. Environ. Qual., 23:1177-1183.

Inbar, Y., Y. Hadar and Y. Chen 1993. Recycling of cattle manure: The composting process and characterization maturity. J. Environmental Quality, 22:857-863.

Inbar,Y., Y. Chen, Y. Hadar and H.A. J. Hoitink.1990. New approaches to compost maturity. Biocycle,31(12):64-69.

Jodice, R.1989. Chemical and biological parameters for evaluating compost quality. In: Institute Agrario Provinciale S. Micheleall Adige(eds.). Proceedings of the compost production and use. International Symposium, pp.363-384.

Keeling, A.A., I.K. Paton and J.A.J. Mullet.1994. Germination and growth of plants in media containing unstable refuse derived compost. Soil. Biol. Biochem.,26:767-772.

Lee, J.T. and M.H. Cho. 2010. Removal of nitrogen in wastewater by polyvinyl alchol(PVA)-immobilization of effective microorganisms. Korean J. Chem. Eng., 27(1):193-197.

Mathur,S.P., G. Owen, H. Dinel and M. Schnitzer.1993. Determination of compost maturity. I. Literature Review. Academic Publishers. pp.65-85.

Misra, R.V., R. N. Roy and H. Hiraoka. 2003. On farm composting methods. Food and Agricultural Organization of the United Nations, Rome Italy.

Mupondi,L. T., P. N. S.Mnkeni and M.O. Brutsch.2006.The effects of goat manure, sewage sludge and effective microorganisms on the composting of pine bark. Compost Science and Utilization, 14(3)201-210.

Raviv, M., S. Tarre, Z. Geler and G. Shelef. 1987. Changes in some physical and chemical properties of fibrous solids from cow manure and digested cow manure during composting. Biological Wastes, 19 (4):309-318.

R. D. A. 1989. Standard methods for the examination of soil chemical properties, Suwon ,Korea

R. D. A. 2009. Compost Notification (2009-95). Rural Development Administration, Suwon, Korea.

Vogtmann, H. and K. Fricke 1989. Nutrient value and utilization of biogenic compost in plant production. Agr. Ecosyst. Environ., 27:471-475.

Zucconi, F., A. Pera and M. Forte. 1981. Evaluating toxicity of immature compost. BioCycle, 2:54-57.

(Received : 26. October. 2009, Accepted : 5. August. 2011) 